
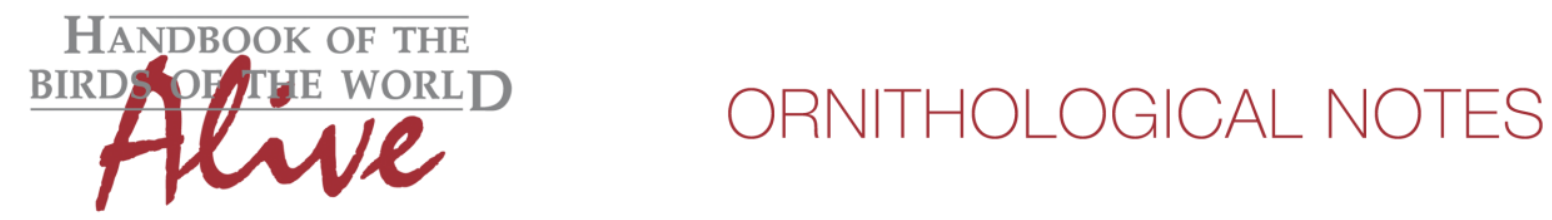

\title{
Notes on the vocalizations of Western Striped Manakin (Machaeropterus striolatus) and Eastern Striped Manakin (Machaeropterus regulus)
}

Peter Boesman

In the following we briefly analyze and compare voice of the different races of Western Striped Manakin (Machaeropterus striolatus) and Eastern Striped Manakin (Machaeropterus regulus). We also try to quantify the extent of any vocal differences using the criteria proposed by Tobias et al. (2010), as a support for taxonomic review. We have made use of sound recordings available on-line from Xeno Canto $(\mathrm{XC})$ and Macaulay Library (ML).

\section{M. regulus}

Song (by ear) is a single note. Closer look on a sonogram shows that the syrinx apparently produces two different notes simultaneously, one low-pitched (flat and slightly decreasing in pitch, the longest in length) and one overslurred at higher pitch. This is thus a so-called polyphonic note, in which presumably both sides of the syrinx work as independent oscillators. The low-pitched note has a fundamental frequency $A$ of $c .700 \mathrm{~Hz}$, the high-pitched note has a fundamental frequency $B$ of $c .3400 \mathrm{~Hz}$. and as a result heterodyne $A-B$ and $A+B$ frequencies etc. are generated, which explains the close pseudo-harmonics around the higher-pitched note.

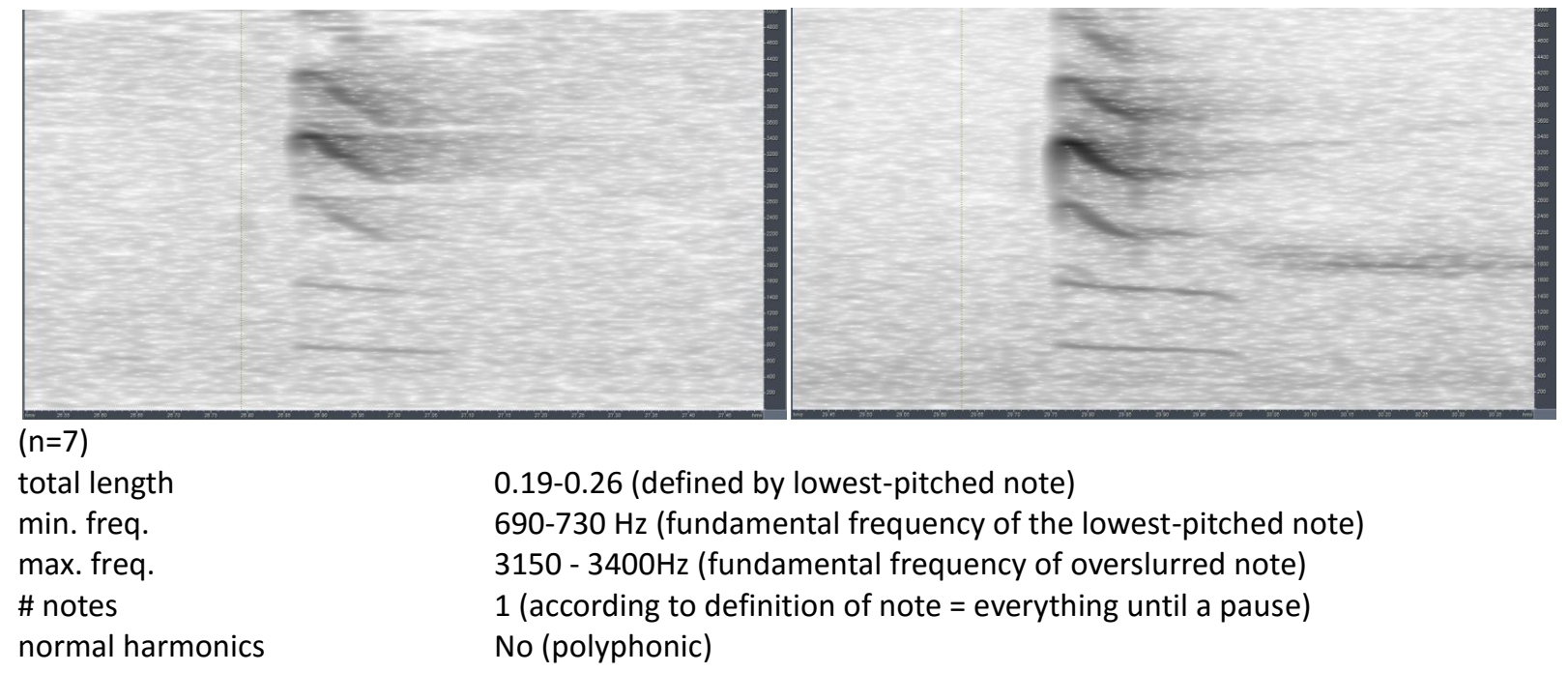

\section{M. striolatus}

All taxa of this group have a a similar song (with slight differences, see table): a short note, which is also strangely composed by a faint lower-pitched flat note and two (?) higher-pitched short notes uttered simultaneously, followed by a pause and an overslurred note with normal harmonics. The first note is thus again a polyphonic note, with apparently a faint flat note at $A$ freq. of c. $1200 \mathrm{~Hz}$ and a short note at B freq. of C. 3400 . 


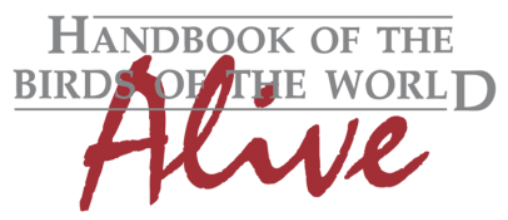

\section{ORNITHOLOGICAL NOTES}

Some examples on sonogram:

antioquiae

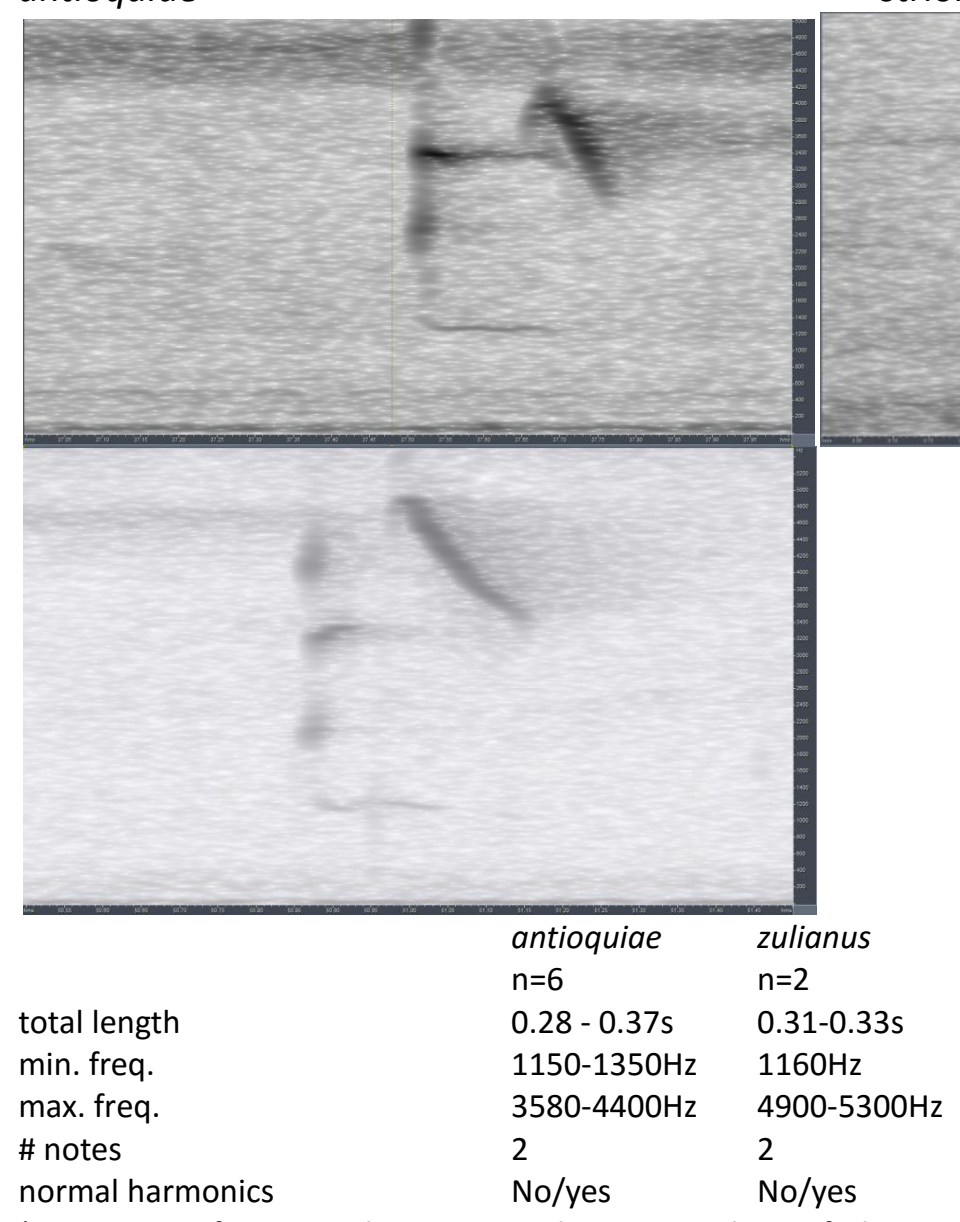

striolatus

$\begin{array}{ll}\text { aureopectus } & \text { striolatus } \\ \mathrm{n}=1 & \mathrm{n}=10 \\ 0.29 \mathrm{~s} & 0.28-0.31 \mathrm{~s} \\ ? & 1200-1280 \mathrm{~Hz} \\ 5400 \mathrm{~Hz} & 4900-5300 \mathrm{~Hz} \\ 2 & 2 \\ \text { No/yes } & \text { No/yes }\end{array}$

(aureopectus from SE Bolivar, Venezuela. No recordings of obscurostriatus)

As can be seen from the table, antioquiae seems to have a slightly lower-pitched second note.

\section{Undescribed foothill race}

Dan Lane kindly posted several recordings on XC of an undescribed foothill race from Peru, with further recordings from others. Unlike the above groups, song here is a single (simply monophonic) note.

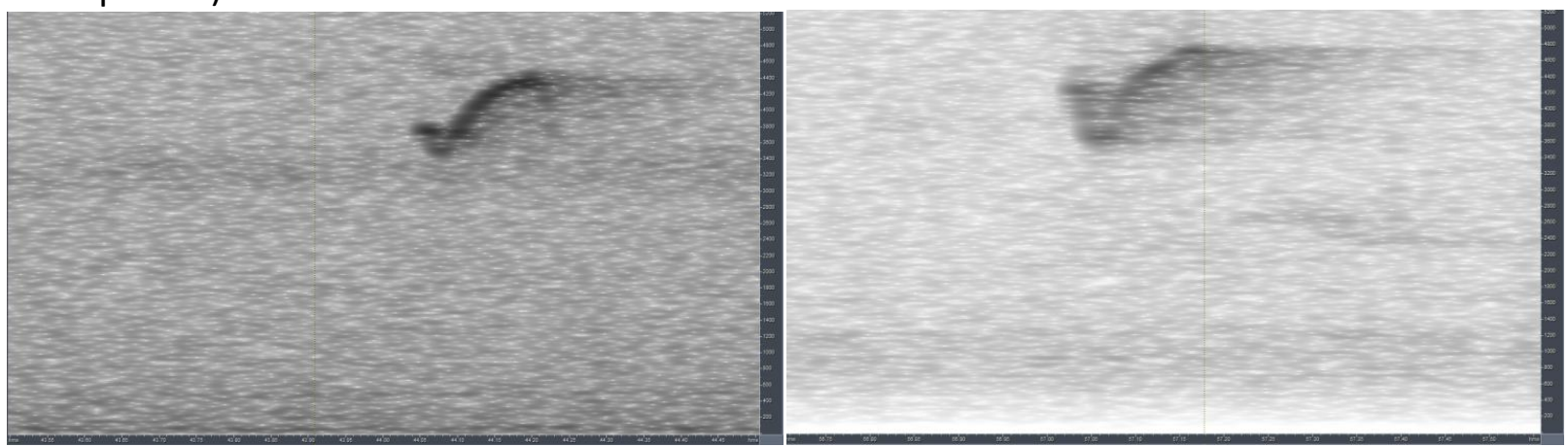

$(n=7)$

total length

min. freq.

max. freq.

\# notes

normal harmonics
$0.15-0.175 \mathrm{~s}$

$2900-3750 \mathrm{~Hz}$

$4100-4950 \mathrm{~Hz}$

1

Y 

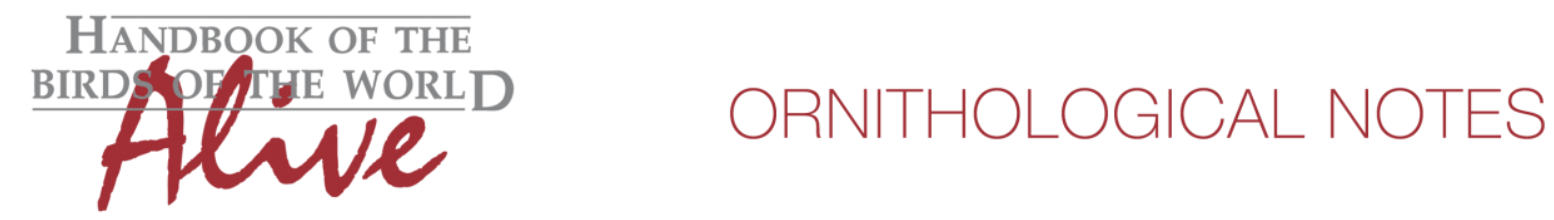

There are thus clearly three vocal groups, which all have a simple (to the ear) but very distinct song. Within each group, the reproducibility among individuals and races is striking (as can be seen from the few sonograms which I have included). This also emphasizes the remarkable distinctiveness of the undescribed race from Peru (which in fact rather has a superficial resemblance to song of Fiery-capped Manikin M. pyrocephalus of the same genus).

From the above measured data, differences are quite obvious and can be summarized and quantified as follows:

regulus vs. striolatus group: regulus has a song consisting of a single (polyphonic) note (score 34) with all comparable elements lower-pitched (score 3), and total length shorter (score 2-3). When applying Tobias creiteria, thus would lead to a total vocal score of 6-7.

regulus vs. undescribed taxon: regulus has a song which consists of a polyphonic note while in undescribed taxon it is a simple monophonic note (score 3 ), which in regulus is clearly lowerpitched (score 3-4) and longer in length (score 2-3). Total vocal score 6-7.

striolatus group vs undescribed taxon: striolatus group has a song composed of a polyphonic and monophonic note while the undescribed taxon has a song consisting of just a single monophonic note (score 3), which in striolatus group thus has a higher number of notes (score 3-4), is much longer (score 3-4), and has a much larger frequency range (score 4). Total score 7.

This note was finalized on 4th September 2015, using sound recordings available on-line at that moment. We would like to thank in particular the sound recordists who placed their recordings for this species on XC and ML: Ciro Albano, Nick Athanas, Peter Boesman, Bradley Davis, Eric DeFonso, Fernando de Godoy, Paul Donahue, Sidnei dos Santos, Jerome Fischer, Pablo Florez, David Geale, Joe Klaiber, Niels Krabbe, Frank Lambert, Dan Lane, Ottavio Janni, Bernabe LopezLanus, Oscar Laverde, Hans Matheve, Jeremy Minns, John V Moore, Ted Parker, Leonardo Pimentel, Alexandre Renaudier, Mark Robbins, Manuel Sanchez, Fabrice Schmitt, Andrew Spencer, Marc Thibault and Mark Todd.

\section{References}

Tobias, J.A., Seddon, N., Spottiswoode, C.N., Pilgrim, J.D., Fishpool, L.D.C. \& Collar, N.J. (2010). Quantitative criteria for species delimitation. Ibis 152(4): 724-746.

\section{Recommended citation}

Boesman, P. (2016). Notes on the vocalizations of Western Striped Manakin (Machaeropterus striolatus) and Eastern Striped Manakin (Machaeropterus regulus). HBW Alive Ornithological Note 190. In: Handbook of the Birds of the World Alive. Lynx Edicions, Barcelona. (retrieved from http://www.hbw.com/node/932131 on 26 August 2016). 